\title{
Palyno-taxonomic studies of some tree species of Fabaceae from Sajjan Niwas Bagh of Udaipur District, Rajasthan, India.
}

\author{
Asha Arora $^{1 *}$ and Paras Bunker ${ }^{2}$ \\ ${ }^{1}$ Department of Biotechnology, B N University, Udaipur (Raj.) India. \\ ${ }^{2}$ Department of Botany, M L Sukhadia University, Udaipur (Raj.) India.
}

Received:2/17/2018;Revised: 2/27/2018; Accepted: 3/24/2018

\begin{abstract}
Green corridors are the key elements of urban ecology. These corridors include both new inceptions and historical gardens. Udaipur the historically glorified city of Rajasthan state holds Sajjan Niwas Bagh is popularly known as gulab bagh as one of the rich urban biodiversity hotspot. It bears numerous tree species among which Baubinia variegata, Cassia auriculata, Delonix regia and Erythrina indica of Fabaceae family can be cited for it's outnumber. These tree species contribute allergenic composition of the area from January to May of the pollen calendar cycle, but their morphological and morphometric analysis scarcely hit the prevailing studies. The present study deals with pollen morphological observations, viability and germination. The morphometric observations were recorded by scanning electron microscopy and it shows that pollen grains of all the studied species differed in shape but except Erythrina indica they were tricolpate. Percent viability and percent germination of Baubinia variegata and Delonix regia was nearly similar while in case of Cassia auriculata and Erythrina indica the percent germination was poor as compared to viability which was comparatively significant. A pollen kit like adhesive structures were observed in Baubinia variegate and Cassia auriculata.
\end{abstract}

Keywords: Baubinia variegata, Cassia auriculata, Delonix regia and Erythrina indica, Sajjan Niwas Bagh, Pollen morphology, Pollen viability, Pollen germination

\section{Introduction}

Among the heritage gardens of Rajasthan, the Sajjan Niwas Bagh popularly known as Gulab Bagh finds the important place because of its rich floral diversity and conservation practices of the past. It has a micro-climate of its own and it is a beautiful green patch which functions as the lungs for Udaipur. Beside the aesthetic value it is a rich botanical station of many diversified plants which have been cultivated over here since 1878 (Bowe, 1999). It is not merely the adorned landscape of ornamented plants or recreational track rather it is an integral and important part of local ecosystem which helps in mitigation of air and noise pollution as well as improves the landscape in a nearby residential area. Tree species form the main contour as they are mainly planted for shade and cooling purposes. Despite of many positive attributes these trees are also the source of pollen allergens which affect the local catchment. Generally, the trees have comparatively light weight pollen grains and are carried by wind. Therefore, they form the major portion of composite air, especially in late winters and early springs and hence are responsible for mild to chronic topical and respiratory allergy.

In Sajjan Niwas Bagh around 67 tree species form the skyline among which Baubinia variegata, Cassia auriculata, Delonix regia and Erythrina indica of Fabaceae forms the chief pollen allergen source (Jain, 1998). Fabaceae is characterized by

*Corresponding Author:

Dr. Asha Arora,

Head, Department of Biotechnology,

B N University, Udaipur (Raj.)

Country India.

E-mail: araudr@gmail.com europalynous pollen, which is characterized with great variation in pollen morphology; however, at the generic level pollen morphology tends to be more consistent (Jose et al., 2014). Pollen grain morphology of the various genera of Fabaceae family is dealt by many workers and forms an important taxonomical assessment parameter (Erdtman, 1969; Melhem, 1971; Ohashi, 1971; Perveen and Qaiser, 1998; Pavlova and Manova, 2000; P1nar et al., 2000). Pollen grains vary in their external features including exine structures with position and structures of colpi and aperture. The pollen viability in turn forms the major parameter for the surveillance of the species as it contributes in the formation of seed and hence lineage to the next generation (Cynthia et al., 2013). The present study aims to attain the palynological characterization of Baubinia variegata, Cassia auriculata, Delonix regia and Erythrina indica to assess their possible role as allergen and their propagating efficiencies through their vitality and germination capabilities.

\section{Materials and Methods}

Collection of pollen material

The polleniferous material of flowers was collected from Sajjan Niwas Bagh in their bloom months as Baubinia variegata (January to March), Cassia auriculata (January to April), Delonix regia (March to May) and Erythrina indica(March and April). Mature flower 
buds were collected in between 6-7AM in sealed polythene bags. Herbarium sheets of studied plants were prepared as per standard protocol and stored in Department of Biotechnology in BNPG College (BNU/ 2016-2017/ PB/ FAB 03, BNU/ 20162017/ PB/ FAB 04, BNU/ 2016-2017/ PB/ FAB 06, BNU/ 2016-2017/ PB/ FAB 07). For morphological characterization and morphometric analysis the pollen source was dried; followed by transfer and storage in glass vials.

\section{Morphometric analysis}

Dried pollen grains were suspended in a drop of ethanol and transpired with a fine pipette to a metallic stubs using double sided cello tape. Stub's were placed in the sputtering chamber for goldpalladium coatings (Polaron sputter Coater). Morphological features of pollen grain were measured using JEOL Scanning electron microscope. Measurements' for pollen size, equatorial axes and polar axes was calculated accordingly.

\section{Pollen Viability test}

Pollen viability test was carried out by the tetrazolium staining method (Oberle and Watson, 1953; Brown, 1954). 1\% TTC (0.2g TTC and $12 \mathrm{~g}$ of sucrose was dissolved in $20 \mathrm{ml}$ of distilled water) was dropped on a glass slide and the pollens were spread with a brush on TTC solution. Pollen viability was counted after two hours. The viability of pollen was scored according to staining level: pollen with Orange or Dark red color as viable, and colorless as non- viable.

\section{Pollen Germination test}

The germination potential of pollen was studied using the hanging drop method. Different sucrose concentration $(10,15$ and $20 \%$ ) was added into media with $0.5 \%$ agarose, $50 \mu \mathrm{l}$ boric acid $\left(\mathrm{H}_{3} \mathrm{BO}_{3}\right)$, $100 \mu \mathrm{l}$ Calcium nitrate $\left(\mathrm{Ca}\left(\mathrm{NO}_{3}\right) \cdot \mathrm{H}_{2} \mathrm{O}\right)$ to determine the effects of sucrose concentrations (10\% to $20 \%)$ on pollen germination. The pollen containing slides were incubated at $27^{\circ} \mathrm{C}$ and observed after 24 hours under the light microscope at $40 \mathrm{X}$ for the respective germination. Germination and viability are expressed in percentage for the evaluation.

\section{Results and Discussion}

The pollen composition of any area at various heights is an index of floral diversity of shrub and tree nature of different heights. The generalized height of a human being is considered in between 4' to 6.3 ' feet. Therefore, medium and large sized trees and large sized shrubs form the maximum composition of allergens. Baubinia variegata, Cassia auriculata, Delonix regia and Erythrina indica are large sized tree and their pollen forms the pollen zone of 5 to 15 feet from ground level. The pollens of all the studied species occurred as monads. Comparative morphological studied reveal that the equatorial axis was smallest for $D$. regia $(17.93 \mu \mathrm{m})$ while $B$. variegata present largest equatorial axis $(63.07 \mu \mathrm{m})$. The pollen axis do not have deeper theoretical implications; it can be treated as a practical means of orientation on the surface of grain and since it is a practical instrument its circumscription should be as practical as possible (Faegri, 1978).

The polar axis of $B$. variegata, $C$. auriculata, D. regia and E. indica was found to be $28.46 \mu \mathrm{m}, 40.55 \mu \mathrm{m}$, $39.65 \mu \mathrm{m}$ and $32.35 \mu \mathrm{m}$ respectively, which forms the $\mathrm{P} / \mathrm{E}$ ratio as $0.45,1.43,2.21$ and 0.91 . The $\mathrm{P} / \mathrm{E}$ ratio chiefly provides the screen of pollen shape (Erdtman, 1952). Therefore, according to $\mathrm{P} / \mathrm{E}$ ratio the shape of $B$. variegata, $C$. auriculata, D. regia and $E$. indica was found to be peroblate, prolate, perprolate and oblate spheroidal (Table 1).

Table 1. Morphological and Morphometric characters of Baubinia variegata, Cassia auriculata, Delonix regia and Erythrina indica pollen grains

\begin{tabular}{|c|c|c|c|c|}
\hline Pollen Characters & $\begin{array}{c}B . \\
\text { variegata }\end{array}$ & $\begin{array}{c}C . \\
\text { auriculata }\end{array}$ & D. regia & E. indica \\
\hline Equatorial Axis $(\mu \mathrm{m})$ & 63.07 & 28.33 & 17.93 & 35.29 \\
\hline Polar axis $(\mu \mathrm{m})$ & 28.46 & 40.55 & 39.65 & 32.35 \\
\hline $\mathrm{P} / \mathrm{E}$ ratio & 0.45 & 1.43 & 2.21 & 0.91 \\
\hline Shape & Peroblate & Prolate & Perprolate & $\begin{array}{l}\text { Oblate- } \\
\text { Spheroidal }\end{array}$ \\
\hline Exine ornamentation & Striate & Regulate & $\begin{array}{c}\text { Reticulate/ } \\
\text { Verrucate }\end{array}$ & Irregular \\
\hline Aperture & Tricolpate & Tricolpate & Tricolpate & Triporate \\
\hline Symmetry & Radially & Radially & Radially & Bilateral \\
\hline Polarity & Isopolar & Apolar & Isopolar & Apolar \\
\hline
\end{tabular}

The exine ornamentation of pollen grain forms the finger print marks of the species (Dorota et al., 2013). Striate, regulate, reticulate/ verrucate and irregular orientations were observed in B. variegata, C. auriculata, D. regia and E. indica respectively. Expect E. indica all the three species were tricolpate where E. indica was found to be triporate. Along with aperture morphology E. indica also differed form the other three species as it has bilateral symmetry while the rest three beared radial symmetry. Pollens of $B$. variegata and $D$. regia were unipolar in nature while $C$. auriculata and E. indica beared apolar pollen grains (Table 1).

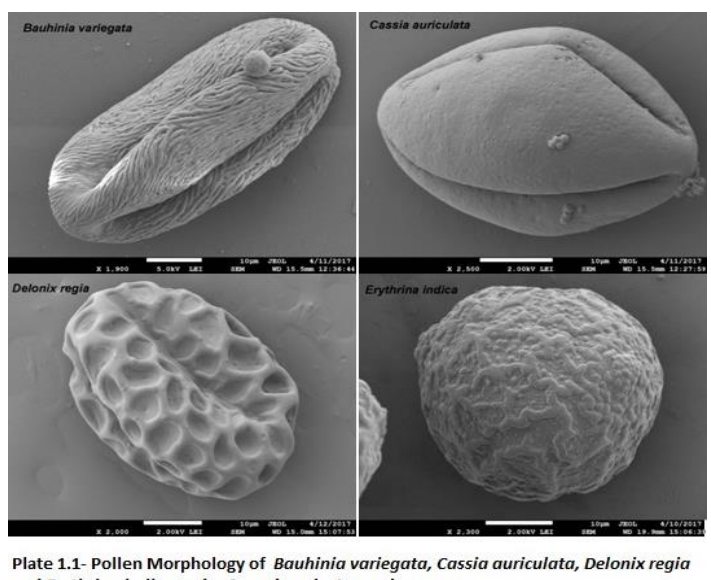
Plate 1.1- Pollen Morphology of Bauhinia variegata, Cass
and Erythrina indica under Scanning electron microscope. 
The SEM micro graphed structures reveal honey comb like meshes on the surface of exine of $D$. regia while pollen kit like adhesive substance were found on B. variegata and $C$. auriculata exine. Such adhesive structure retain grains into anther till dispersal and enable pollen packaging by bees; being resistance protects pollen from water, UV radiation and other particles and allergens (Wang et al., 2017) (Figure 1.1).

Pollen viability and pollen germination forms an important parameter to access the amount of progenitor in the composite floral community. Higher the pollen viability and pollen germination, higher account of fertilized units can be expected (Fei and Nelson, 2003).

The pollen viability and germination was nearly equal for $B$. variegata while slightly it differed in $D$. regia. In $C$. auriculata the $50 \%$ pollens were viable, but the germination scored up to $25 \%$ only. In $E$. indica $56.25 \%$ pollens were viable, but germination was merely one third (Graph 1.1). In C. auriculata and E. indica the low germination rate, despite of significant viability may be an attribute of some peripheral or extrinsic factor due to which the pollen being viable was not able to germinate (Abdelgadir et al., 2012). Hindering role of gynocase is not possible as the germination experiment was carried out in vitro. The probable extrinsic factor may include nutrition, $\mathrm{pH}$ or the presence of inhibitors.

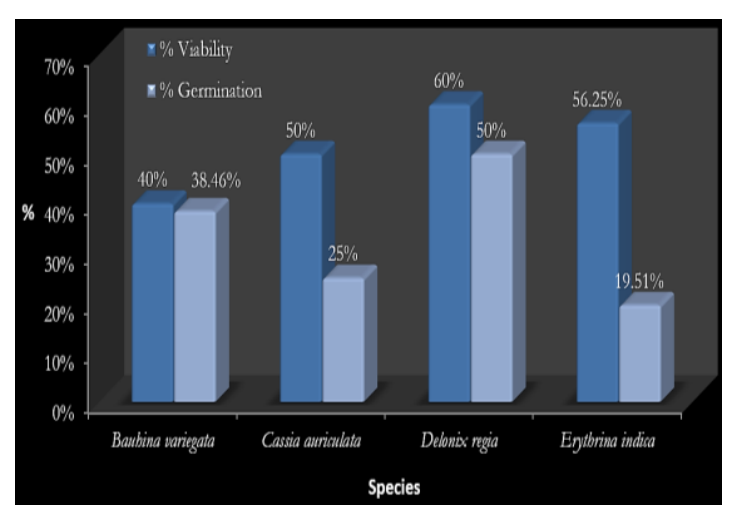

Graph 1.1: Germination Score

\section{Conclusion}

Sajjan Niwas Bagh, the prominent green corridor of Udaipur city is lushed with green crowns of prominent B. variegata, $C$. auriculata, D. regia and $E$. indica. Among the studied tree species grains of $D$. regia are smallest while $B$. variegate grains to be largest. These two species have nearly equal viability and germination capacity while $C$. auriculata and $E$. indica showed comparatively lower germination values. Therefore, it can be concluded that $B$. variegata and $D$. regia form major risk zone of pollen allergens as compared to C. auriculata and E. indica.

\section{References}

1. Abdelgadir, H A, S D Johnson and S J Van. "Pollen viability, pollen germination and pollen tube growth in the biofuel seed crop Jatropha curcas (Euphorbiaceae)." South African Journal of Botany 79 (2012): 132-39.

2. Bowe Patrick. "The Indian Gardening tradition and the Sajjan Niwas Bagh, Udaipur." The Garden History Winter 27.2 (1999): 189-205. The garden history society.

3. Brown Walter V. "A preliminary study of the staining of plant cells by tetrazolium chloride." Bulletin of the Torrey Botanical Club 81.2 (1954): 127-36. Torrey botanical Society.

4. Cynthia F P, DA Luz, Maki S Erica, Ingrid Horak Terra, Vidal Torrado Pablo and Mendonka Filho Carlos victor. "Pollen grain morphology of Fabaceae in the Special Protection Area (SPA) Pau-de-Fruta, Diamantina, Minas Gerais, Brazil." Annals of the Brazilian Academy of Sciences 85.4 (2013): 1329-44. Academia Brasileira de Ciencias.

5. Dorota, Wronska Pilarek and Bocianowski Jan, Jagodziński M Andrzej. “Comparison of pollen grain morphological features of selected species of the genus Crataegus (Rosaceae) and their spontaneous hybrids." Botanical Journal of the Linnean Society 172.4 (2013): 555-71. Linnean Society of London.

6. Erdtman, Gunnar. "Handbook of Palynology, Morphology, Taxonomy and Ecology: an introduction to the study of Pollen grains and spores" (1969). Copenhagen, Denmark.

7. Erdtman, Gunnar. "Pollen morphology and plant taxonomy Angiosperm. In Introduction to Palynology." Almqvist and Wiksell 1 (1952) Stockholm, Chronica Botanika Co.

8. Faegri K. "What is polar axis?" Grana 17 (1978): 1516. Stockholam.

9. Fei, S and E Nelson. "Estimation of pollen viability, shedding pattern, and longevity of creeping bentgrass on artificial media." Crop Science 43 (2003) 2177-81. Crop Science Society of America.

10. Jain Rachna. "Garden Flora of Udaipur." Ph. D. Thesis, Mohan Lal Sukhadia University, Udaipur (Raj.) (1998).

11. Jose E, Bravo-Chinguel, Delgado Paredes Guillermo $\mathrm{E}$ and Consuelo Rojas Idrogo. "Pollen morphology of Peruvian prosopis (Fabaceae)." Journal of Global Biosciences 3.4 (2014): 714-24.

12. Melhem T. "Pollen grains of plants of the CerradoLeguminosae-Lotoideae. Tribe Phaseoleae.” Hoebnea 1 (1971): 119-51.

13. Oberle, D G and R Watson. "The use of 2,3,5 triphenyl tetrazolium chloride (TTC) in viability test of fruit pollen." Journal of the American Society for Horticultural Science 61 (1953): 299-03. American Society of Horticultural Sciences. 
14. Ohashi H. "A taxonomic study of the tribe Coronilleae (Leguminosae) with special reference to pollen morphology." Journal of the Faculty of Science (Tokyo) 11 (1971): 25-92. Tokyo, Japan.

15. Pavlova, K Dolja and Vasilissa I Manova. "Pollen morphology of the genera Onobrychis and Hedysarum (Hedysareae, Fabaceae) in Bulgaria." Annales Botanici Fennici 37.3 (2000): 207-17.

16. Perveen, Anjum and Mohammad Qaiser. "Pollen flora of Pakistan - X. Leguminosae (subfamily: Caesalpinioideae)." Turkish Journal of Botany 22 (1998): 145-50. Ankara (Turkey).

17. Pinar, N M, C Vural and Z Aytac. "Pollen morphology of Ebenus L. (Leguminosae: subfamily Papilinoideae) in Turkey." Pakistan Journal of Botany 32.2 (2000): 303-10
18. Tilak S T. "Renaissance of Aerobiology. Proc. 17th." National Conference of Indian Aerobiological Society on Impact of Airborne Microbes (2012): 1.

19. Wang, L, L A Clarke, R J Eason, C C Parker, B Qi, R J Scott and J Doughty. "PCP-B class pollen coat proteins are key regulators of the hydration checkpoint in Arabidopsis thaliana pollen-stigma interactions." New Phytologist 213.2 (2017): 764-77. Wiley- Blackwell.

\section{Cite this article as:}

Asha Arora and Paras Bunker. Palyno- taxonomic studies of some tree species of Fabaceae from Sajjan Niwas Bagh of Udaipur District, Rajasthan, India. Annals of Plant Sciences 7.4 (2018) pp. 2194-2197.

do $\mathrm{http}: / / \mathrm{dx}$. doi.org/10.21746/aps.2018.7.4.20 